\title{
Perseverance is required!
}

\author{
Armin Curt $^{1}$ \\ Received: 13 March 2019 / Accepted: 15 March 2019 / Published online: 8 April 2019 \\ (c) International Spinal Cord Society 2019
}

More than 15 years ago, a movement called the International Campaign to Cure Paralysis (ICCP) was inspired and initiated by spinal cord injury (SCI) clinicians, researchers, and funders. The ICCP came together to support the translation of preclinical findings toward clinical trials for promising interventions. Subsequently, five consecutive guideline papers were published for dissemination [1-5]. These were regularly referenced by SCI trialists and regulatory offices in the clinical trials that followed. Not surprisingly, the SCI community continues to encounter many challenges (e.g., enrollment issues which are common to clinical trials in many disease indications), including some daunting experiences (i.e., the relatively high frequency of prematurely terminated trials) that "beg" for a critical appraisal of lessons learned. While these experiences may be perceived by many as continuous failures and unresolvable struggles, an international interdisciplinary group of clinicians, researchers, and funders (many who were also involved with ICCP) accepted again the challenge to search for feasible solutions following a meeting in 2016. With the support of SCI foundations, the group focused their activities around specific topics dedicated to Spinal Trials, Understanding, Design, and Implementation (STUDI), and generated follow-up guideline papers aiming to discuss progress, since the ICCP papers, as well as tackling other areas require attention.

The actual STUDI paper titled "The Challenge of Recruitment for Neurotherapeutic Clinical Trials in Spinal Cord Injury" [6] exemplifies areas where substantial lessons have been learned and valuable progress could be achieved while also pointing to areas of continuous and even novel unsolved challenges. Together, the STUDI papers are intended to facilitate the development of innovative SCI

Armin Curt

Armin.Curt@balgrist.ch

1 Spinal Cord Injury Center, University Hospital Balgrist, Zurich, Switzerland clinical trials by addressing persistent and new barriers to their success.

As we encourage our patients to persevere when facing the distinct struggles of living with SCI, those working in the area of SCI should also heed this advice of perseverance!

\section{Compliance with ethical standards}

Conflict of interest The author declares that he has no conflict of interest.

Publisher's note: Springer Nature remains neutral with regard to jurisdictional claims in published maps and institutional affiliations.

\section{References}

1. Adams M, Cavanagh JF. International Campaign for Cures of Spinal Cord Injury Paralysis (ICCP): another step forward for spinal cord injury research. Spinal Cord. 2004;42:273-80.

2. Fawcett JW, Curt A, Steeves JD, Coleman WP, Tuszynski MH, Lammertse D, et al. Guidelines for the conduct of clinical trials for spinal cord injury as developed by the ICCP panel: spontaneous recovery after spinal cord injury and statistical power needed for therapeutic clinical trials. Spinal Cord. 2007;45:190-205.

3. Steeves JD, Lammertse D, Curt A, Fawcett JW, Tuszynski MH, Ditunno JF, et al. International Campaign for Cures of Spinal Cord Injury Paralysis. Guidelines for the conduct of clinical trials for spinal cord injury (SCI) as developed by the ICCP panel: clinical trial outcome measures. Spinal Cord. 2007;45: 206-21.

4. Tuszynski MH, Steeves JD, Fawcett JW, Lammertse D, Kalichman M, Rask C, et al. International Campaign for Cures of Spinal Cord Injury Paralysis. Guidelines for the conduct of clinical trials for spinal cord injury as developed by the ICCP panel: clinical trial inclusion/exclusion criteria and ethics. Spinal Cord. 2007;45: 222-31.

5. Lammertse D, Tuszynski MH, Steeves JD, Curt A, Fawcett JW, Rask C, et al. International Campaign for Cures of Spinal Cord Injury Paralysis. Guidelines for the conduct of clinical trials for spinal cord injury as developed by the ICCP panel: clinical trial design. Spinal Cord. 2007;45:232-42.

6. Blight AR, Hsieh J, Curt A, Fawcett JW, Guest JD, Kleitman N, et al. The challenge of recruitment for neurotherapeutic clinical trials in spinal cord injury. Spinal Cord. (2019). https://doi.org/10.1038/ s41393-019-0276-2 [Epub ahead of print]. 